Ks. ZDZISLAW KLIŚ

\title{
SCENA ZASLLUBIN W PARYSKICH DEKRETALACH GRZEGORZA IX. JEJ TRADYCJA IKONOGRAFICZNA I TEOLOGICZNA
}

Na miniaturach-Dekretalów Grzegorza IX znajdujących się w Gnieźnie (Ms. 88, inicjał „D”, 2 polowa XIII w., [il. 1] ${ }^{1}$ i w Krakowie (rkp. 379, fol. $323 \mathrm{v}$, początek XIV w. [il. 2]) ${ }^{2}$ ukazany jest moment zaślubin, w którym asystujący kaplan, ubrany w szaty liturgiczne, stojący pośrodku między narzeczonymi podającymi sobie ręce, trzyma ich za przeguby rąk. W przeciwieństwie do sceny krakowskiej, gdzie narzeczeni trzymają we wzajemnym uścisku prawą dłoń, na miniaturze gnieźnieńskiej panna młoda wyciąga do narzeczonego prawą rękę zaś on podaje jej lewą dłoń, a prawą trzyma na piersi. Na miniaturze krakowskiej narzeczony kładzie na pierś lewą dłoń. Jest też znaczące to, że w przedstawieniu krakowskim za narzeczonymi stoją dwie postacie: za narzeczoną - kobieta $\mathrm{z}$ nakryciem głowy (w białej ,guimpe" $z$ niską, ,koroną" 3 ), natomiast za narzeczonym - mężczyzna, również mający głowę zakrytą. Narzeczeni nie mają żadnego nakrycia głowy. $\mathrm{Na}$ miniaturze gnieźnieńskiej narzeczona nosi podobne nakrycie głowy jak na miniaturze krakowskiej kobieta stojąca za narzeczoną, chociaż zamiast korony zastosowana jest tu niska czapeczka. Tak na

${ }^{1}$ Katalog zabytków sztuki w Polsce, województwo poznańskie, powiat gnieźnieński. Red. T. Ruszczyńska, A. Sławska. Inwentaryzację przeprowadziły T. Ruszczyńska, A. Sławska $\mathrm{i}$ inni. T. V, z. 3, s. 55, il. 238; A. Karłowska-Kamzowa, Gotyk w kodeksach iluminowanych i malowidlach ściennych Wielkopolski (od końca XIII do poczqtku XVI w.). W: Malarstwo gotyckie w Wielkopolsce, studia o dzielach i ludziach. Praca zbiorowa pod red. A. S. Labudy. Poznań 1994, s. 36, il. 1.

${ }^{2}$ Z. Ameisenowa, Rekopisy i pierwodruki iluminowane Biblioteki Jagiellońskiej. Wroclaw-Kraków 1958, s. 81, il. 122.

3 Tamże, s. 81 . 
miniaturze gnieźnieńskiej jak i krakowskiej kobiety mają uniesioną do góry lewą rękę, jakby w geście mowy ${ }^{4}$ lub świadectwa.

Gnieźnieński kodeks, zawierający glosy Bernarda z Parmy do tekstu Grzegorza IX i Novellae constitutiones Innocenti $I V \mathrm{z}$ aparatem glos Bernarda z Compostelli (oba teksty z bullą publikacyjną dla Paryża), nie jest jedynym, który dochował się do naszych czasów w Bibliotece Kapitulnej. Dwa inne Dekretaly Grzegorza IX, jeden z lat ok. 1286-93 z bullą publikacyjną skierowaną do Bolonii i ofiarowany katedrze gnieźnieńskiej przez biskupa poznańskiego Jana III (Ms. 29) i drugi, z 2. połowy XIII w. (Ms. 82), obydwa ,cum glossa ordinaria Bernardi Parmensis”, nie mają przedstawień figuralnych ${ }^{5}$. Krakowskie Dekretaly (Decretalium libri quinque) legowane przez Jana Poniatowskiego, archidiakona krakowskiego, zmarłego w Mogile w 1476 r., także nie są jedynymi w Bibliotece Jagiellońskiej. Manuskrypt Decretalium librii $V$ cum glossa, Grzegorza IX (Rkp. 370), z zapisem: „In die decollacionis s. Johannis incepi s. XXVIII Augusti 1369 in civitate Florentie ubi inchoavi officium 12 May...", został zakupiony w 1445 r. przez Tomasza ze Strzempina, biskupa krakowskiego i następnie podarowany „pro Collegio artistarum in Cracovia”. Zawiera on na fol. 275: „Incipit liber de sponsalibus” wraz z miniaturą, na której, jak pisze Z. Ameisenowa: „Na szafirowym tle w biały drobny ornament papiez siedzi na żółtym składanym krześle $\mathrm{z}$ poręczami w kształcie głów zwierzęcych (motyw francuski). Za plecami papieża jest zawieszona karminowa tkanina... Papież prawą ręką w liturgicznej rękawiczce błogosławi młodej parze, stojącej na prawo. Młodzieniec w sukni różowej wkłada pierścień na palec narzeczonej w ciemnozielonej sukni" (il. 3).

Wszystkie elementy zawarte $\mathrm{w}$ opisie, jak: podanie sobie rąk przez narzeczonych, kapłan stojący pomiędzy nimi i trzymający ich za nadgarstki, pierścionek ślubny, osoby stojące za narzeczonymi, mają w rycie małżeńskim sobie właściwe znaczenie. Odczytanie go w wyżej wspomnianych kodeksach XIII i XIV-wiecznych to zadanie niniejszego opracowania.

Wedlug E. Panofskiego, tłumaczącego obraz Malżeństwo Arnolfich z 1434 r. Jana van Eycka, prawo kanoniczne przy końcu obrzędu zaślubin nakazywało złożenie przysięgi (fides), która wyrażała się w dwóch czynnościach: polączeniu dłoni (fides manualis) i uniesieniu ręki (fides levata), ze strony narzeczonego. Jednak tego rodzaju gesty widoczne są w przedstawieniach zaślubin z XIII, XIV i XV w., niezależnie od tego czy jest to ceremonia małżeńska Dawida i Mikal, czy Perseusza i Andromedy ${ }^{6}$ i się-

${ }^{4}$ M. Barasch, Giotto and the Language of Gesture. Cambridge 1990, s. 15-39.

${ }^{5}$ Katalog zabytków sztuki w Polsce. T. V, z. 3, s. 54-55.

${ }^{6}$ E. Panofsky, Early Netherlandish Painting. Its Origins and Character. T. 1. Icon edition. New York-Hagerstown-San Francisco-London 1971, s. 202. 
gają swoimi początkami IV w., co pokazuje scena zaślubin na rzymskim sarkofagu zwanym Annona w Muzeum Term, gdzie małżonkowie podają sobie prawe dłonie? . Odbywający się w zbliżony sposób obrzęd przedstawiają liczne miniatury z XIII-XV w. zarówno w rękopisach kodyfikacji justyniańskiej (scena zaślubin była ukazywana $\mathrm{z}$ reguły na początku księgi XXIII Digestów, a także na początku księgi V Kodeksu, którą rozpoczyna również tytuł De sponsalibus), jak i w rękopisach prawa kanonicznego, zwłaszcza Dekretów Gracjana (w obrębie ostatnich dziecięciu causae [XXVII-XXXV] traktujących o małżeństwie). W rękopisach kodyfikacji justyniańskiej, powstałych w północnej Francji (w większości zapewne w Paryżu) około polowy i w 3. ćwierci XHI stulecia - a więc w grupie najwcześniejszych egzemplarzy Corpus iuris civilis z cyklem miniatur figuralnych na początku ksiąg, scena zaślubin komponowana jest $\mathrm{z}$ reguły symetrycznie, $z$ kapłanem stojącym pośrodku i łączącym prawe dłonie oblubieńców (Lyon, Palais des Arts. Codex Ms. 43, fol. 112r, Paryż, około 1250-60. [il. 4]; Paryż, Bibliothèque Nationale, Digestum vetus. Ms. Fr. 20118, fol. CCLIIr, Paryż, 3. ćwierć XIII w. [il. 5] ${ }^{8}$; Paryż, Bibliothèque Nationale, Digestum vetus, Ms. Fr. 495 fol. 261r, Paryż ok. 1270-80 r.). W jednym z najwcześniejszych znanych rękopisów kodyfikacji justyniańskiej z cyklem miniatur figuralnych na początku ksiąg, jakim jest rękopis Corpus iuris civilis w Bibliotece Królewskiej w Kopenhadze (GL. kgl. S. 393, powstały w Paryżu okolo 1250 r.) w scenie zaślubin, umieszczonej na początku księgi VIII (fol. 432v), kapłan stojący pomiędzy podającymi sobie prawe ręce oblubieńcami, czyni gest błogosławieństwa (il. 6) ${ }^{9}$.

D. Forstner cytując wypowiedź J. Pinska pisze, że gdy czlowiek podaje drugiemu rękę, dotyka nie tylko fizycznej części jego ciała, ale poprzez nią także „całej duchowej osoby drugiego, jego miłości, wierności, gotowości do poświęcenia siebie czy do przebaczenia" ${ }^{10}$. Wedlug Augustyna, podanie

7 J. Lafontaine-Dosogne, Iconographie de l'enface de la Vierge dans l'empire hyzantin et en Occident. T. 1. Bruxelles 1964, il. 67.

8 R. Branner, Manuscript Painting in Paris during the Reign of Saint Louis. Berkeley, Los Angeles, London 1977, s. 80, 106, 218, 222, 229, il. 192; Krakowski egzemplarz, ukazujący centralnie stojącego biskupa łączącego prawe dłonie narzeczonych, pochodzi z Bolonii (pocz. XIV w., Biblioteka Jagiellońska, rkp. 374. fol. 128v), patrz: A. Karłowska-Kamzowa, L. Weteski, Katalog wystawy (zorganizowanej w dniach 12 1X-31X 1991 przez Muzeum Począlków Państwa Polskiego w Gnieźnie przy współpracy Instytulu Historii Sztuki LAM w Poznaniu). W: Średniowieczna ksiqżka rękopiśmienna jako dzielo sztuki. Griezno 1993, ni katalogu 13, s. 58.

"R. Branner, The Copenhagen Corpus. „Konsthistorisk Tidskrift” XXXVIII (1969) s 104-105, fig. 13; Tenże, Manuscript Painting in Paris, s. 115-117. Pragnę serdecznie ponzękować Pani Annie Palińskiej za sugestie i materiał porównawczy do naszych miniatur.

if J. Pinst, Die sakramentale Welt, Fryburg 1938; D. Forsner OSB, Świat symboliki chrexiciarichiej. Warszawa 1990, s. 351. 
prawicy jest ,signum concordiae, signum consonantiae". Takie znaczenie miało również dwoje złączonych ze sobą rąk, wytłaczanych na monetach rzymskich. „Dexterarum coniunctio" jako ,signum concordiae" pojawiało się w przedstawieniach zmarłych małżonków w antycznej płaskorzeźbie sarkofagowej albo na złotych kielichach, których prawdopodobnie używano w czasie uczty weselnej ${ }^{11}$. Na nagrobku z XVI w. w Lwówku Śląskim lub w scenie zaślubin Henryka I i Jadwigi Śląskiej (w kodeksie z Legenda ostrowskq św. Jadwigi, spisanym przez Mikołaja Pruzię, z 1353 r., obecnie w Getty Museum w Malibu) para małżeńska podająca sobie prawe dłonie, nawiązuje także do zachodniej kultury, rycerskiej miłości rycerza-męża do kobiety-żony ${ }^{12}$. Podanie ręki u Rzymian, jako znak zawieranego małżeństwa, związane bylo ze zróżnicowaną formą tego aktu. Rozróżniano małżeństwo $\mathrm{z}$ władzą męża nad żoną (matrimonium cum manu) i małżeństwo bez władzy męża nad żoną (matrimonium sine manu). Według pierwszego zwyczaju zawarcie małżeństwa dokonywało się za pomocą jednego z trzech aktów prawnych: confarreatio, coemptio, usus. Confarreatio było najstarszą, uroczystą i sakralną formą zawarcia małżeństwa. Nazwa określająca zaślubiny pochodzi od specjalnego chleba, zwanego panis farreus, ofiarowanego Jowiszowi i uważanego za symbol życia osiadłego. Przy zaślubinach obecny był najwyższy kapłan (pontifex maximus), kapłan Jowisza (flamen Dialis) i dziesięciu świadków, a w czasie ceremoniału wypowiadano przeznaczone na tę okazję słowa. Coemptio była formą zawarcia małżeństwa przez symboliczne kupno żony. W roli kupującego występowal przyszły mąż, w roli zaś sprzedającego - początkowo pater familias, tutor, a $w$ późniejszym okresie sama kobieta. Usus był rodzajem zawarcia małżeństwa na podstawie wspólnego pożycia małżeńskiego, trwającego nieprzerwanie cały rok. Małżeństwo sine manu zawierano nieformalnie przez wyrażenie wzajemnej zgody małżeńskiej oraz wprowadzenie żony do domu męża. Miała tu zastosowanie zasada: Consensus facit nuptias. Dopełnienie małżeństwa nie było wymagane do jego ważności. Wprowadzenie żony do domu męża uwaźano za środek dowodowy zawarcia małżeństwa. Ta forma zawarcia małżeństwa $\mathrm{z}$ czasem stała się powszechna ${ }^{13}$. Zwracając uwagę na znaczenie podania ręki w momencie zaślubin i związanych $z$ tym aktem konsekwencji prawnych, można przypomnieć wielkiego rzymskiego

11 D. Forsiner, jw., s. 351, il. 143; C. Reinsberg, Concordia. Die Darstellung von Hochzeit und ehelicher Eintracht in der Spätantike. W: Spätantike und frühes Christentum: Ausstellung im Liebieghaus Museum alter Plastik. Frankfurt am Main 16 December 1983 bis 11 März 1984/ Hrsg. v. H. Beck u. P. C. Bol. Frankfurt a. M. 1983, s. 312-317.

12 A. Grzybkowski, Die Dextrarum iunctio auf dem Grahmal in Löwenherg. „Zeitschrift für Kunstgeschichte" 47 (1984), s. 59-69, il. 1.

${ }^{13}$ Ks. T. Pawluk, Prawo malìeńskie wedlug kodeksu Jana Pawla II. Prawo malìeńskie. T. III. Olsztyn 1984, s. $174-175$. 
jurystę Ulpiana, który powiada, że nie konsumpcja (cuncubitus), ale obopólna zgoda (consensus) narzeczonych lub rodzin na ślub, albo mówiąc inaczej nie skonsumowanie (coitus) lecz decyzja na związek (maritalis affectio) sprawia, że zostaje zawarte małżeństwo.

Przynajmniej do IX w. w oczach duchownych, a niewątpliwie nawet wcześniej w świadomości wielu w Kościele katolickim, consensus oznaczał wzajemną zgodę partnerów na małżeństwo, a affectio, obok decyzji, przybrało również formę sentymentu i uczucia. Wzajemne przyrzeczenia lub wymiana pierścionków kryły w sobie słowo consensus. Centralnym elementem wśród przyrzeczeń byla consumatio, będąca również dziedzictuem starego Testamentu. Już w XII w., z powodu różnych lokalnych tradycji, sądy kościelne stanęły wobec faktu zdefiniowania prawa małżeńskiego. Czołowi kanoniści, jak również papieże, oglosili consensus jako podstauę dla zaistnienia małżeństwa. Ale powstała także dyskusja na temat, czy consumatio jest istotne do pełności malżeństwa. Vacarius н. Summa de Matrimonio mówi o wzajemnej zgodzie na małżeństwo, Gracjan uznaje consensus jako podstawę dla zaistnienia małżeństwa, a consumatio jako sprawiające, że jest ono doskonałe. W prawie małżeńskim Aleksandra III zrodziły się dwie trudności (które przyszło rozstrzygać także šu. Tomaszowi dwa pokolenia później), a mianowicie z jednej strony papież Aleksander III akceptował consensus jako podstawę i minimum dla zauarcia małżeństwa, podobnie jak to było w prawic rzymskim, jednak z drugiej strony akceptując prawo Justyniana rozumial, że wzbranianie się przed consumatio moglo dowodzić impotencji i prowadzić do nieważności małżeństwa, ponieważ niezdolność ta jest przeszkodą małżeńską. Okazał też wahanie, jako że rzymska tradycja zachęcała partnerów do pozostania razem u przypadku impotencji i zadowolenia $z$ powodu pozostania razem oraz korzystania $z$ innych dobrodziejstw państwa, zaś galijski zwyczaj był za ich rozdzieleniem. Aleksander był na rozdrożu w trzech kierunkach: staral się zachować zastany zwyczaj (również tolerować tradycję galijską), uwzględniać przyrzeczenia, jeśli były złożone prawdziwie, i dodatkowo był glẹboko świadom zdania una caro (Mt 19, 5-6; Mk 10, 8), a więc stwierdzenia, że consumatio jest fundamentalne dla prawdziwego charakteru małżeństu:a ${ }^{15}$.

-4 Ch. Brook, The Medieval Idea of Marriage. Oxford 1994, s. 128-131. Gracjan i jego zwolennicy (szkola bolońska) byli zdania, że małżeństwo, które nie zostało dopełnione, jest dopiero zapocząlkowane (matrimonium inochoatum), dlatego nie jest bezwzględnie nierozwiązalne i nie stanowi przeszkody węzła; dopiero copula facit matrimonium, patrz: C. $35-38$, C. XXVII, q. 2.

${ }^{15}$ Tamże, s. 132-133. Św. Tomasz zauważył, że consensus nie mógłby być prawdziwy jeśli polwierdzałby niezdolność partnerów do małżeństwa. Impolencja czyni małżeństwo njeważnym. Takie stanowisko polwierdzają słowa św. Pawła w 1 Kor 7, 3-4. Aleksander III 
Centralnym pytaniem Gracjana, jak i wielu kanonistów jedenastego i dwunastego wieku było: jaki element konstytuuje małżeństwo legalnie ważne i związane? Był to problem, który został przedyskutowany i rozwiązany w papieskim sądzie ${ }^{16}$. Kanoniści sformułowali mniej więcej tak brzmiącą definicję: kiedy mężczyzna i kobieta w sposób wolny i prawowity zdecydowali się na małżeństwo - i bez żadnych warunków, w obecności świadków ogłosili siebie mężem i żoną - to nie ma już odwrotu; tylko uznanie nieważności tego związku może ich rozdzielić. Jeśli ktoś powiedział, że przyrzeka wziąć kobietę za żonę $w$ przyszłości, to byli oni zaręczeni, ale nie zaślubieni. Jeżeli jednak wyraził się, że przyrzeka pojąć kobietę za żonę teraz i tutaj (verba de praesenti), był już zobowiązany do zrealizowania swoich słów, chociaż może w sposób nie pełny, aż nie nastąpi consumatio. Zawarcie małżeństwa $w$ sposób wolny i prawowity oznaczało, że narzeczeni powinni być w wieku pozwalającym im prawnie podjąć decyzję zawarcia związku ${ }^{17}$ (kobieta powinna mieć przypuszczalnie dwanaście lat a mężczyzna czternaście, chociaż wiele związków faktycznie było zawieranych wcześniej ${ }^{18}$ ), niemożliwe było, aby byli związani przysięgą malżeńską $\mathrm{z}$ inną osobą, ale też, jak odważnie wyrazil się papież Adrian IV, nawet w przypadku niewolników nie mogli oni być skrępowani czynnikami zewnętrznymi, które by wpłynęły na ważność malżeństwa, zależnego tylko do ich własnej decyzji. Definicja pojawiła się już w papieskiej praktyce lub papieskich dekretach około 1140 r. a szczegółowo została opracowana przez Piotra Lombarda w jego Sententiae w 1150 r. i ostatecznie ugruntowana przez papieża Aleksandra III w jego serii dekretów w 1160 r. ${ }^{19}$

W Decretum Gracjana szereg miniatur ukazuje kapłana stojącego pomiędzy narzeczonymi i nawet trzymającego jedną ze stron za nadgarstek, jednakże tłumaczą one różne przeszkody związane $\mathrm{z}$ zawarciem prawowitego i ważnego małżeństwa, lub wskazują na różne nieprawidlowości i trudności w malżeństwie. W causa XXVII omówiony został

ustalił, iż małżeństwo zawarte de presenti uniemożliwia rozerwanie związku, chyba że stwierdzi się jego nieważność lub oboje małżonkowie wstąpili do klasztoru, patrz: R. Ch. Brooke, Popular Religion in Middle Ages: Western Europe 100-1300. London 1985, s. 113.

${ }^{16} \mathrm{~J}$. Dauviller, Le mariage dans le droit classique de l'Eglise. Paris 1933, rozdz. 1-2; J.A. Brundage, Law, Sex, and Christian Society in Medieval Europe. Chicago 1987, rozdz. 17-8.

17 Ch. Brooke, jw., s. 137-138.

${ }_{18}$ Średniowieczne prawo odziedziczyło rozwiązanie prawa rzymskiego, że zaręczyny nie powinny się odbyć poniżej siódmego roku życia a consensus w wieku zdolnym do rozrodczości, czyli w dwunastym roku życia w przypadku dziewczyny i czternastym roku odnośnie do chłopca, patrz: J. Dauviller, jw., s. 43-48; P. E. Corbell, The Roman Law of Marriage. Oxford 1930, s. 51-52.

19 Ch. Brooke, jw., s. 138. 
przypadek, w którym mężczyzna zaręczony $\mathrm{z}$ inną kobietą powziął decyzję, aby zachować czystość. Kobieta, po rozeznaniu sytuacji, poślubiła innego mężczyznę. W związku $\mathrm{z}$ tym $\mathrm{w}$ kodeksie przechowywanym w Bibliothèque Nationale w Paryżu (Ms. lat. 3898, fol. 285) mężczyzna stojąc po lewej stronie kapłana trzymającego jego dłoń, ściskając dłoń narzeczonej będącej po drugiej stronie duchownego, wskazuje na świątynię usytuowaną obok siebie. W causa XXVIII Gracjan mówi, że każdy kto ożenił się przed przyjęciem chrztu i po przyjęciu chrztu poślubił drugą kobietę, popełnia bigamię. $\mathrm{Na}$ miniaturze w kodeksie $\mathrm{z}$ Bibliothèque Comunale w Laon (Ms. lat. 1898, fol. 293), ukazany jest kapłan stojący pośrodku i łączący dłonie narzeczonych, w obecności pierwszej żony narzeczonego. Causa XXIX wskazuje na podstawę rozwiązania małżeństwa w przypadku, kiedy szlachetnie urodzony otrzymał zgodę na małżeństwo ze strony narzeczonej (która jednak nie miala możności go zobaczyć i osobiście poznać), lecz inny „osobnik" nie szlachetnie urodzony, ale niższego pochodzenia, podstępnie podając siebie za wyżej wymienionego zająl jego miejsce. I w tej sytuacji wyżej wspomniany kodeks paryski (Ms. 3898, fol. 397) ukazuje kapłana ujmującego 'rękę narzeczonej stojącej po jego lewej stronie, zaś narzeczony, którym jest szlachetnie urodzony lub wspomniany oszust, ściska dłoń narzeczonej, jednakże na głowie wyrastają mu rogi jak u jelenia. Mężczyzna odwrócony tyłem do narzeczonej, z sakiewką w jednej ręce i sokolem w drugiej, to także albo szlachetnie urodzony, albo oszust. W związku z causa XXXI również wiele miniatur ukazuje kapłana pośrod$\mathrm{ku}$, między narzeczonymi podającymi sobie dłonie: w kodeksie monachijskim (Bayerische Staatsbibliothek. Ms. CLM. 18050a, fol. 347), gdzie kapłan trzyma narzeczonych za ręce; w kodeksie w Cambrai (Bibliothèque Municipale. Ms. C. 623, fol. 270) i w kodeksie watykańskim (Biblioteca Apostolica Vaticana. Ms. Ross. lat. 307, fol. 292v). Ponieważ ten punkt dotyczy mężczyzny, który zgwałcił żonę innego, podczas gdy on jeszcze żyl, a po jego śmierci ożenil się z nią, zaś spłodzoną razem córkę bez zgody jej samej i już żony wydał za mąż, na miniaturach kodeksów, obok zawieranego związku małżeńskiego, któremu pośrodku narzeczonych asystuje kaplan, ukazana jest albo trumna (Paris, Bibliothèque Nationale. Ms. lat. 16898 , fol. 323v), albo łoże z umierającym poprzednim mężem (Paris, Bibliothèque Nationale. Ms. lat. 3898, fol. 302v). W causa XXXII zadane jest putanie, czy mężczyzna może ożenić się z kobietą jedynie w celu zaspokojenia popędu seksualnego, oraz inne pytania: czy może mieć dzieci ze służąca, podczas gdy jego żona żyje; czy może ożenić się $\mathrm{z}$ inną kobietą, kiedy jego żona zaginie; czy może opuścić kobietę w przypadku stwierdzec:a jej cudzołóstwa; czy może poślubić niewierzącą osobę. Szereg miniatur przy okazji tego problemu ukazuje tylko kapłana pośrodku, między narzeczonymi (Vatican, Biblioteca Apostolica Vaticana. Ms. 2491, fol. 478; 
Laon. Bibliothèque Comunale. Ms. 372, fol. 168; Paris, Bbiliothèque Nationale. Ms. 3898, fok. 304v; Münich, Bayerische Staatsbibliothek. Ms. Clm. 18050a, fol. 349). Zwracając uwagę na stałość i nierozerwalność małźeństwa wedlug Mt 19, 9 i Rz 7, 1-3, w causa XXXIII Gracjan rozważa prawne sytuacje: po pierwsze czasową impotencję i wynikły stąd ponowny ożenek jako nieusprawiedliwiony i niemożliwy (cudzolóstwo), oraz ślub czystości $w$ małżeństwie jako niezgodny $z$ przyrzeczeniami małżeńskimi. $\mathrm{Na}$ miniaturze kodeksu berlińskiego (Staatsbibliothek Preussischer Kulturbesizt. Ms. Ham. 279, fol. 195v) mąż stojąc przed biskupem wskazuje palcem żonę leżącą w łóżku $\mathrm{z}$ innym mężczyzną, oraz na jej ponowne małżeństwo, ukazane powyżej łoża, gdzie pomiędzy kobietą i mężczyzną stoi kapłan, jedną ręką podtrzymując ich połączone w uścisku dlonie. W Psalterzu Mistrza Honoré z 1288 r. (Tours, Bibliothèque Municipale. Ms. 558, fol. 285v) ukazany jest cywilny sędzia ujmujący delikatnie rękę cudzołożnej kobiety, aby na nowo polączyć ją z pierwszym mężem. $\mathrm{Na}$ miniaturze $\mathrm{w}$ angielskim kodeksie (Cambridge. Fitzwilliam Museum. Ms. 262, fol. 86v) w dolnej części miniatury ukazane jest drugie, cudzołożne małżeństwo i-obok ponowne połączenie cudzołożnej żony z pierwszym mężem.

W causa XXXV autor zwraca uwagę na niemożliwość małżeństwa $\mathrm{z}$ osobą spokrewnioną zbyt blisko poprzez więzy krwi lub małżeństwa, co widoczne jest na miniaturze kodeksu w Laon (Bibliothèque Comunale. Ms. 372, fol. 243v), w której powyżej zmarłej żony, spoczywającej w łożu i przykrytej kirem, stoi mężczyzna ściskający dłoń następnej, przyszłej żony, podtrzymywaną przez stojącego pośrodku nich kapłana. Po lewej i prawej stronie narzeczonych stoją prawdopodobnie świadkowie sakramentu małżeństwa ${ }^{20}$.

Obecność kapłana lub biskupa w wyżej wymienionych miniaturach w momencie zaślubin oznacza, że Kościół zawsze pragnął, aby małżeństwo było zawierane w świątyni wobec duchownego (in facie ecclesiae) ${ }^{21}$, tym bardziej, że jest ono sakramentem. Już św. Augustyn pisał, że dobre

20 A. Melnikas, The Corpus of the Miniatures in the Manuscripts of Decretum Gratiani. „Studia Gratiana” XVIII, vol. III. Roma 1975. Causa XXVII, s. 863-864, PI. III; Causa XXVIII, s. 887-888, Гig. 12, Pl. II; Causa XXIX, s. 915-916, PL. II; Causa XXXI, s. 969-970, lig. 25, 26, 28. Pl. II; Causa XXXII, s. 995-997, PI. I, lig. 9, 16, 33; Causa XXXIII, s. 1029-1031, fig. 17, 20, 23; Causa XXXV, s. 1109-1110, fig. 24.

21 Już legat papieski, Piotr z Kapui, w 1197 r. pozostawił w Polsce nakaz zawierania małżeństw in facie ecclesiae. Statuty legata Jakuba z Leodium, wydane na synodzie we Wrocławiu w 1248 r. dotyczyły zaręczyn, zapowiedzi, sposobu zawierania małżeńsiw, niektórych przeszkód małżeńskich. Zagadnienia małżeńskie zoslały szczegółowo opisane w pierwszym urzędowym zbiorze prawa Kościoła polskiego z 1420 r., patrz: Statuty synodalne wieluńsko-kaliskie Mikołaja Trąby z r. 1240. Z materiałów przysposobionych przez 
małżeństwo charakteryzuje fides, proles, sacramentum ${ }^{22}$. Autorytatywnie na sakramentalność malżeństwa zwrócono uwagę w 1274 r. na Soborze Liońskim ${ }^{23}$, a jako dogmat wiary ogłoszono na Soborze Trydenckim ${ }^{24}$. W XIII w. próbowano zdefiniować materię i formę sakramentu, która dla jednych znajdowala się $w$ formule obietnicy i zgody - w słowach, a dla innych spoczywała $w$ wewnętrznej zgodzie na małżeństwo. Dla Alberta Wielkiego forma spoczywała w wewnętrznej zgodzie na małżeństwo, dla św. Tomasza w słowach, Duns Szkot pragnął odnaleźć ją w słowach, ale był zaklopotany wielkością zwyczajów lokalnych, co oznacza, że były stosowane różne formuły przysięgi. Inni widzieli formę sakramentu w błogosławieństwie kapłańskim, a Glosa Ordinaria do Dekretów papieża Grzegorza IX poszła tak daleko, że uzasadniając przyczynę, dla której blogosławieństwo kapłańskie $w$ drugim związku (kiedy jeden $z$ partnerów pierwszego małżeństwa żyje) nie mogło być udzielone stwierdzała, iż forma sakramentu nie może być powtórzona.

Pierwsze całościowe rytuały z końca XI i z początku XII w. zawierały takie elementy jak: wymiana podarunków, wzajemne przyrzeczenia, błogosłauieństuo kapłana, msza św. ślubna i błogosławieństwo sypialni małżeńskiej. Zachowalo się również szereg ksiąg podających miejsca kościoła, w których dokonywały się poszczególne akty ceremonii zaślubin. W mszale z Rennes w Bretanii z XII w. Ordo informuje: ,najpierw ksiądz przychodzi przed drzwi kościola (ante ostium ecclesiae) ubrany w albę i stułę, z wodą śuięconą". W pontyfikale z opactwa Lyre w Normandii, z początku XII w., jest powiedziane: „,niech ci, którzy zostaną połączeni na małżeńskim kobiercu podejdą do drzwi kościoła (ad januas ecclesiae) przed wielu świadków". Każdy z partnerów wyraża własną zgodę, wiano kobiety jest potwierdzane i jakieś pieniądze są pozostawiane, aby mogły być rozprowadzone wśród ubogich. Panna mloda oddana jest narzeczonemu przez ojca lub przyjaciól i przyjęta przez niego na dobre $i$ na złe (w zdrowiu i u chorobie) aż do końca życia, przez ujęcie jej za prawą rękę. Pierścionek jest pobłogoslawiony i położony na trzech palcach prawej ręki narzeczonej, przy udziale kapłana, w imię Ojca, Syna i Ducha Świętego, a następnie pan młody układa go narzeczonej na palec lewej ręki. Potem następuje modlitua i blogoslawieństwo. Następnie „młodzi" wchodzą do kościoła, padają na twarz $w$ nawie, a kapłan odmawia nad nimi pozostale modlituy, po czym wstają i wchodzą do chóru, pozostając po prawej

22 C. Brokke, jw., s. 276; Patrz także: Patrologia Latina, Migne, 40, 394; 44, 424.

${ }^{23}$ Professio fidei a Michaele Paleologo Gregorio X oblata: „Tenet etiam et docet eadem Sancta Romana Ecclesia septem esse ecclesiastica Sacramenta, unum scilicet Baptismum... aliud est Matrimonium". Codicis luris Canonici fontes (= Fontes). Wydał P. Gasparri. T. I, nr 35, s. 33.

24 T. Pawluk, jw., s. 24. 
stronie (w czasie kolejnych części rytuału trzymając świece), nawet kiedy msza św. jest celebrowana. Po Sanctus nowożeńcy kładli się twarzą ku ziemi w pozie modlitewnej, a czterech mężczyzn rozpościerało kawałek tkaniny nad nimi, każdy trzymając za jeden koniec. W czasie Pax powstawali, pan młody otrzymywal z rąk kapłana znak pokoju i przekazywał go już swojej żonie przez pocałunek. Msza św. kończyła się komunią św. i błogosławieństwem, a cały ryt błogosławieństwem w nocy sypialni nowo zaślubionych ${ }^{25}$.

Jednak malżeństwo nie zawsze bylo zawierane w kościele, tym bardziej, że obecność duchownego nie byla konieczna do jego ważności. Definicja małżeństwa przejęta przez papieża Aleksandra III w $1160 \mathrm{r}$. wymagała zawarcia związku w obecności świadków i stanowiła zasadnicze minimum do jego ważności aż do Soboru Trydenckiego. Ewidencja z sądu kościelnego w Ely, Canterbury i York pokazuje, że dużo małżeństw z niższych warstw społecznych nie było zawieranych w kościele. W Tuluzie wiele malżeństw stawało przed notariuszem. W Niemczech znaczna ilość małżeństw była zawierana $\mathrm{w}$ domu ${ }^{26}$.

W każdym razie w Polsce we wloskim (z Apulii) Pontyfikale $\mathrm{z}$ końca XIII w., ofiarowanym dla katedry gnieźnieńskiej przez biskupa Jana Rzeszowskiego w latach 1435-50 (Ms. 152) ${ }^{27}$, wskazującym na kościół jako miejsce zawierania małżństwa w obecności kapłana, zastosowany został obrzęd zaślubin zbliżony do francuskiego. Ceremoniał pierścionka, jego kolejne wkładanie na trzy palce, pojawia się już w wyżej wspomnianym rytuale klasztoru Lyre z XII w., także formuła wypowiadana przez narzeczonego przypomina formułę francuską z Rouen z XIV w., chociaż rytuałom francuskim nie było znane pytanie zwrócone do mundoala kobiety ( $\mathrm{tj}$. osoby, pod której władzą kobieta pozostaje, odpowiadającej na pytanie, czy chce oddać kobietę mężowi obok niej stojącemu). Ten termin techniczny był właściwy prawu longbardzkiemu i aż do końca Średniowiecza był stosowany we Włoszech, stąd przypuszcza się, że nasz obrzęd jest pochodzenia włoskiego ${ }^{28}$. Różnica przy wkładaniu pierścionka jest niewielka.

${ }^{25}$ Ch. Brooke, jw., s. 249-250, 278; D. Barthelemy, Kinship. W: A History of Private Life. Revelations of the Medieval World. Edilor G. Duby. Translator A. Goldhammer. Cambridge, Massachusetts and London. England 1988, s. 130. Na temat velatio nuplialis symbol velamen celeste w rycie sakramentu malżeństwa patrz: A. Melnikas, jw., s. 997-1000, il. $23,24,25,26,27,28$.

26 Ch. Brooke, jw., s. $251-253$.

${ }^{27}$ Katalog zabytków sztuki w Polsce. T. V. Województwo poznańskie. Red. T. Ruszczyńskia i A. Sławska. Z. 3, Powiat gnieźnieński, inwentaryzację przeprowadziły T. Ruszczyńska i A. Slawska i inni, s. 52.

${ }^{28}$ Z. Obertyński, Pontificale Jana Rzeszowskiego $w$ Bibliotece Kapitulnej w Gnieźnie. Lwów 1930, s. 274-275. 
W obrzędzie zawartym w Pontyfikale biskupa Rzeszowskiego kapłan święci pierścionek przez pokropienie go wodą święconą i podaje go narzeczonemu, a ten przyjmując go do prawej ręki i wkładając narzeczonej kolejno na palec wielki i wskazujący, pozostawia go ostatecznie na palcu średnim, równocześnie wypowiadając formulę: tym pierścionkiem cię poślubiam, a tymi pieniędzmi cię obdarzam (cześć ci okazuję) i wianuję: ,de isto anulo te sponso et de hoc argento te honoro et doto" ${ }^{29}$. Dodać trzeba, że kiedy w XII-wiecznym kodeksie z Lyre na początku rytuału następuje połączenie rąk narzeczonych, w Pontyfikale Rzeszowskiego w tym momencie kapłan pyta każdego z osobna, czy chcą się pobrać, oraz czy mąż chce żonie według prawa okazywać szacunek i dochować jej wierności, a żona, czy chce mu być posłuszna, miłować go i uznawać jego władzę ${ }^{30}$.

Do powyższych rozważań można jeszcze dopowiedzieć, że wspomniany już legat papieski Piotr z Kapui w 1197 r. nakazał zawierać małżeństwa w obliczu Kościoła, co uszczegółowiono na wroclawskim synodzie legackim w 1248 r.: małżeństwo ma być zawierane publicznie w kościele, wobec proboszcza narzeczonej, i poprzedzone trzema zapowiedziami; narzeczeni winni wypowiadać słowa ,biorę sobie ciebie za żonę [... za męża]" trzymając się za ręce. Rytuał biskupa Henryka z Wierzbna przekazuje obrzęd ślubu kościelnego $\mathrm{z}$ poświęceniem pierścionka (jednego) i wyrażaniem zgody przez nowożeńców w bramie kościoła (więc dosłownie ,w obliczu kościola”) oraz modlitwami za nowożeńców w czasie mszy św. ${ }^{31}$

Tak więc połączenie rąk jak i pierścionek w Dekretalach Grzegorza IX oznaczały consensus na małżeństwo, którego istotnym dopelnieniem, jak na to wskazują dyskusje teologiczne, było consumatio. Przy czym o ile przyrzeczenia i polączenie rąk stanowiły werbalną i gestykulacyjną część zaślubin, o tyle pierścionek był zewnętrznym, materialnym znakiem zaistnialego faktu. Wydaje się, że w Dekretalach Grzegorza $I X$ ujęcie przez kapłana za przeguby połączonych dłoni narzeczonych, sam gest dextrarum iunctio oraz gesty uniesienia ręki i polożenia jej na piersi, mogą podkreślać ważność słów przysięgi wypowiedzianej przez narzeczonych, ich wewnętrznej zgody, jak i błogosławieństwa kapłańskiego jako formy sakramentu. Gesty te bowiem występują na miniaturach we wszystkich kodeksach, niezależnie od poglądów ich autorów. Tradycja motywów ikonograficznych jest w tym przypadku niezmienna, zmienia się jedynie tekst, obok którego one występują. Dla wydobycia ukrytego znaczenia małżeńskiego

29 Tamże, s. 274.

30 Tamże, s. 274.

${ }^{31} \mathrm{~K}$. Dola, Religijność rycerstwa śląskiego i mieszczan w XIII wieku. W: Bitwa legnicka. Historia $i$ tradycja. Red. W. Korta. Wroclaw-Warszawa 1994, s. 345-346. 
pierścionka znamienne są słowa jego blogosławieństwa zawarte w Pontyfikale biskupa Rzeszowskiego: „Benedic domine anulum hunc quem nos in tuo nomine benedicimus ut qui eum portaverit in tua pace consistat et in tua voluntate permaneat et in amore tuo vivit et senescat et multiplicetur in longitudinem dierum per..."

Oraz inna zamienna modlitwa: „Creator et conservator humani generis dator gratie spiritualis: largitor eterne salutis tu domine emitte benedictionem tuam super hunc anulum: ut virtute celesti defensi illis qui portaverint proficiant ad salutatem per..." 32

Jak mówi rytuał $\mathrm{z}$ Lyre, obrzęd zaślubin miał miejsce $\mathrm{w}$ obecności świadków, tzn. wszystkich, którzy byli obecni w czasie zawarcia sakramentu małżeństwa. Jednakże, chociażby orzeczenie Aleksandra III wskazuje na to, że w obrzędzie małżeńskim brali udzial świadkowie $\mathrm{z}$ urzędu.

32 Bibliotka Kapitulna w Gnieźnie, Pontificale, Ms. 149, k. 165 r. 